\title{
Influence of Weathering on Surface Roughness of Thermally Modified Wood
}

\author{
Eli Keržič, Boštjan Lesar, and Miha Humar* \\ Wood is one of the most important building materials. Thermally modified \\ wood is entering the market and replacing wood preservatives and tropical \\ wood species in some applications. Thermally modified wood is exposed \\ to weathering similarly as other wood-based building materials. It has been \\ reported that if thermally modified wood is exposed to weathering, its \\ moisture performance might decrease fairly fast. Moisture performance \\ reflects the material's ability to remain dry and dry out fast when wet. The \\ aim of this study was to determine whether this phenomenon is associated \\ with crack formation or roughness. Norway spruce, thermally modified \\ spruce, wax-treated thermally modified spruce, and European larch \\ heartwood samples were exposed to artificial accelerated weathering and \\ natural weathering for 9,18 , and 27 months. Samples were subsequently \\ isolated, and their roughness was determined with a confocal laser \\ scanning microscope on axial and longitudinal surfaces at $10 x$ and $50 x$ \\ magnification. After weathering, roughness increased on both axial and \\ longitudinal surfaces. This was evident from the profile 2D measurements \\ $\left(R_{a}\right)$ and surface 3D measurements $\left(S_{a}\right)$. The effect of natural weathering \\ on roughness was higher than artificial accelerated weathering, \\ presumably due to synergistic effects of abiotic and biotic factors. This \\ may be associated with Wenzel's theory on the influence of roughness on \\ the contact angles of water on the surface; namely, increased roughness \\ will decrease the contact angle on hydrophilic surfaces.
}

Keywords: Cracks; Norway spruce; Thermal modification; Water performance; Wax

Contact information: University of Ljubljana, Biotechnical Faculty, Jamnikarjeva 101, Ljubljana, Slovenia

*Corresponding author: miha.humar@bf.uni-lj.si

\section{INTRODUCTION}

Wood and wood-derived materials have been among the most important building materials for millennia (Cheung 2019). Due to its positive environmental impact, functional properties, and availability, the use of wood has increased considerably in central Europe in recent decades, and this trend is likely to continue (EU Commission 2019). Wood in outdoor applications is frequently exposed to weathering and degradation organisms (Martínez et al. 2005; Humar et al. 2020a). However, specific wood durability is required to meet users' and specifiers' criteria for target applications (Kutnik et al. 2014). Because the majority of traditional biocides are banned due to environmental and health concerns (Humar 2017), because of the negative public perception of existing biocides and the use of tropical wood, research strategies for improving the durability and prolongation of the service life of wood have focused on alternative directions (Militz 2015).

In the last two decades, there has been a notable increase in the use of thermally modified wood for a variety of non-structural building applications (Goli and Todaro 2018). Modification of wood is described as the persistent change of wood to increase its inherent durability, to improve its dimensional stability, and to address other relevant 
properties (Hill 2006). The principle of thermally modified wood is to make copious, lessdurable wood species, i.e., Scots pine, Norway spruce, aspen, or black poplar, more durable and dimensionally stable. Modified wood species perform more like durable wood species, at least in above-ground applications (Esteves and Pereira 2009; Humar et al. 2019). Thermal modification of wood can be understood as partial pyrolysis in a chamber with a reduced oxygen concentration, resulting in a changed chemical composition of the treated material. The first signs of hemicellulose modification appear at fairly low temperatures. However, marked degradation of hemicellulose starts at $140{ }^{\circ} \mathrm{C}$ and $\alpha$-cellulose at $150{ }^{\circ} \mathrm{C}$ (Zauer et al. 2016). Lignin is more resistant to higher temperatures (Cerc Korošec et al. 2009). One of the most important consequences of thermal modification is the reduction of readily available hydroxyl groups (Tjeerdsma and Militz 2005). The equilibrium moisture content of thermally modified wood is thus much lower than that of non-modified wood when determined under the same climatic conditions (Scheiding et al. 2016; Brito et al. 2018; Kozakiewicz et al. 2019; Humar et al. 2020b). Water exclusion efficacy is one of the key parameters influencing wood performance in above-ground outdoor applications (Meyer-Veltrup et al. 2017).

Sorption properties and water performance of non-weathered thermally modified wood has been addressed multiple times, predominately under laboratory conditions (e.g. Metsä-Kortelainen 2011; Hill et al. 2012; Olek et al. 2013; Pelaez-Samaniego et al. 2013; Nasir et al. 2019). When the water performance of thermally modified wood is addressed in outdoor conditions, two patterns of performance are determined. If wood is exposed in use class (UC) 2 according to EN 335 (2013) conditions, relative humidity (RH) and occasional wind-driven rain is the prevalent factor influencing wood moisture content (MC). This can be seen from the excellent correlation between the RH and MC of wood (Humar et al. 2020b). The results of moisture monitoring of wood exposed in UC 2 conditions are usually in line with the laboratory data (Welzbacher et al. 2009; Kržišnik et al. 2018a; Humar et al. 2020b). Namely, the moisture content of thermally modified wood is significantly lower than that of reference non-modified wood species (Yildiz et al. 2011). In contrast, when thermally modified wood is exposed in UC 3.1 or even UC 3.2 conditions according to EN 335 (2013), the correlation between water performance in laboratory and outdoor applications is no longer as obvious. The MC of wood exposed in UC 3.1 and 3.2 is affected by relative humidity, but to an even greater extent by rainfall. There have been a number of reports (Van Acker et al. 2015; Žlahtič and Humar 2016a; Žlahtič-Zupanc et al. 2018) that show the moisture performance of thermally modified wood in UC 3 applications, decreases over time. Specifically, thermally modified wood takes up much more water after several months of weathering than non-weathered material or nonmodified wood. This can be seen from the increased MC of thermally modified wood.

The aim of this study was to address one of the possible reasons for this phenomenon. The water performance of thermally modified wood can be improved with the application of hydrophobic systems, such as waxes (Humar et al. 2017). The suggested hypothesis is that cracks of various dimensions are formed on the surface of the thermally modified wood. These cracks act like capillaries, in which water moves into the narrow spaces - capillary action. Surface roughness was determined in this study with a confocal laser scanning microscope after various periods of weathering of thermally modified and non-modified wood. 


\section{EXPERIMENTAL}

\section{Materials}

The present research is a follow-up of previously published articles (Žlahtič and Humar 2016a,b; Žlahtič-Zupanc et al. 2018). Samples prepared in the laboratories of University of Ljubljana and analyzed in these previous studies were used for the experiment. The preparation of the specimens and aging procedures are described in detail in Žlahtič and Humar (2016b).

The study included samples of Norway spruce (Picea abies (L.) H. Karst.) heartwood and European larch heartwood (Larix decidua Mill.). Norway spruce is considered to be the most important wood species for construction purposes in Europe. In contrast, larch is one of the first choices for architects for decking applications in central Europe, predominately in the Alpine region. Thermally modified wood is one of the alternatives for larch in cladding and decking applications. In addition, larch can serve as a reference material, due to its good water performance (Lesar et al. 2019). Spruce wood is classified as a less durable wood species ( $4^{\text {th }}$ to $5^{\text {th }}$ durability class) according to EN 350 (2016), while larch is considered to be slightly more durable, and classified as a moderately durable wood species ( $3^{\text {rd }}$ to $4^{\text {th }}$ durability class). Specimens $(1.5 \mathrm{~cm} \times 2.5 \mathrm{~cm} \times 5.0 \mathrm{~cm})$ were defect-free, without visible presence of fungal decay or discoloration, as recommended in standard EN 113 (2006). The 25 spruce samples were treated with natural wax or thermal modification. Ring width at samples was uniform and was $2.5 \mathrm{~mm}$ for spruce specimens and $1.8 \mathrm{~mm}$ for larch specimens. The average density of the oven-dried specimens was $411 \mathrm{~kg} / \mathrm{m}^{3}$ for spruce, and $681 \mathrm{~kg} / \mathrm{m}^{3}$ for larch wood specimens.

\section{Treatment of Specimens}

Four different materials were included in the experiment. One set of Norway spruce (PiAb) specimens and one set of European larch (LaDe) specimens were untreated, two sets of spruce specimens were thermally modified (TM PiAb), and one of these was treated with wax emulsion (TMW PiAb).

The thermal modification was performed according to the industrial Silvapro® process (Rep et al. 2012). This process is characterized by an initial vacuum. Modification of the wood was performed for $3 \mathrm{~h}$ at $230^{\circ} \mathrm{C}$. The entire process took approximately $24 \mathrm{~h}$. To improve the hydrophobic properties of wood, one set of samples was treated with a $10 \%$ natural wax suspension (Humar et al. 2017). Impregnation was performed according to the full-cell process (30 min vacuum $(8 \mathrm{kPa}), 120$ min pressure $(800 \mathrm{kPa}), 15$ min vacuum $(8$ $\mathrm{kPa})$ ).

\section{Aging Procedures}

Artificially accelerated weathering (AAW) and outdoor aging, with three different exposure times, were applied. Artificially accelerated weathering was carried out in a chamber (ATLAS UP, Suntest XXL+, Atlas, Linsengericht, Germany). The most severe conditions, typical of exterior use, were applied according to EN/ISO 11341 (2004) recommendations. This exposure simulated outdoor weathering without the contribution of biotic factors, because severe UV radiation prevents fungal growth. The specimens were exposed in alternating cycles of elevated temperature $\left(38^{\circ} \mathrm{C}\right)$ and a relative humidity $(68 \%)$ with UV radiation $\left(0.35 \mathrm{~W} / \mathrm{m}^{2}\right)$ and artificial rain for $1000 \mathrm{~h}$. One cycle of AAW lasted for $120 \mathrm{~min}$ and consisted of water spray (18 min) and UV radiation (102 min). After isolation, all samples were stored in the dark under laboratory conditions until further 
characterization of the surfaces. Three sets of specimens $(3 \times 20)$ were exposed to outdoor weathering in the field test site of the Department of Wood Science and Technology, University of Ljubljana, Ljubljana, Slovenia (N 4602` 55.4“", E 14²8`44.6“", $293 \mathrm{~m}$ above sea level). In Ljubljana, the average temperature is $10.4{ }^{\circ} \mathrm{C}$, annual precipitation $1290 \mathrm{~mm}$, and a Scheffer Climate Index score of 55.3. Actual climate data are reported already (Žlahtič-Zupanc et al. 2018). There were five separate sets of samples used. After isolation, samples were not exposed to weathering. The first set of exposed material (OutA) remained outside from January 2014 to October 2014. The second set of materials (OutB) was aged for 18 months, from January 2014 until August 2015, while the third set (OutC) of specimens was isolated after 27 months of exposure (May 2016). After isolation, all samples were stored in the dark under laboratory conditions until further characterization of the surfaces.

\section{Characterization of the Wood Surface}

The surface of the samples was characterized in this study by a laser scanning confocal microscope Olympus LEXT OLS5000 (Tokyo, Japan). First, 2D and 3D images of the longitudinal (L) and cross-sectional (CS) surfaces were recorded at 10x and 50x magnification. The location of measurements was chosen randomly. Three samples for each combination of material and aging were analyzed. At 10x magnification, the image $(3.6 \mathrm{~mm} \times 5.9 \mathrm{~mm})$ in the center of the sample was recorded, being represented for the whole surface. At 50× magnification, we selected three points per sample, one in the earlywood area, another in the latewood area, and the third analysis was performed between early and latewood. Images at 50× magnification covered an area of $0.26 \mathrm{~mm} \times 0.26 \mathrm{~mm}$.

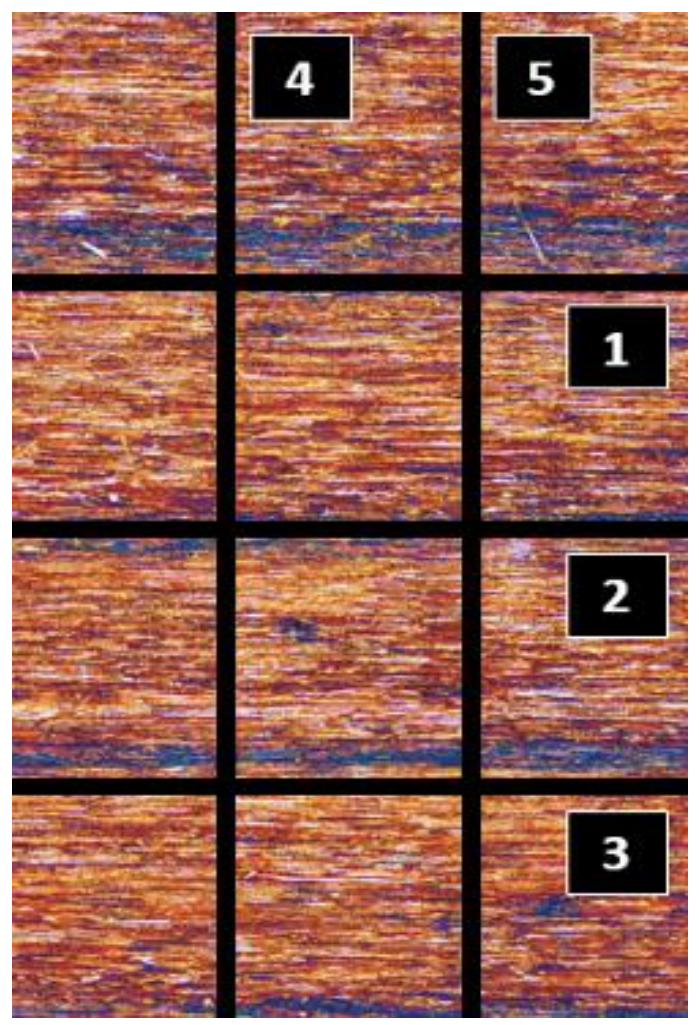

Fig. 1. Pattern of lines in which the profile roughness was measured on images taken at $10 x$ magnification (1,2, and 3- measurements of profile roughness parallel to the growth rings; 4 and 5- measurements of profile roughness perpendicular to the growth rings) 
The profile roughness and areal roughness were measured using Olympus software (OLS50-BSW, Tokyo, Japan). The profile roughness was measured only on the images recorded at $10 \times$ magnification. A similar pattern of measurement was performed with all of the images, as shown in Fig. 1. On every sample, there were 10 profile roughness measurements performed. Several roughness parameters were calculated from the recorded surface; however, only the following representative parameters are given: $R_{\mathrm{a}}$ and $S_{\mathrm{a}}$. The $R$ values reflect the outcomes of 2D analysis, while the $S$ parameters reflect outcomes of 3D analysis. Both $R_{\mathrm{a}}$ and $S_{\mathrm{a}}$ are arithmetical mean heights indicating the average of the absolute value along the sampling length (Gadelmawla et al. 2002). Statistical analysis of the data was performed with Microsoft Excel (Microsoft Corp., v.2019, Redmond, WA, USA), GraphPad prism (GraphPad Software, v.9.0, San Diego, CA, USA), and using the RCommander program (Rcommander.com, v.2.6-x, Hamilton, Canada). For all results (for each type of measurement separately), the total variance was analyzed using one-way analysis of variance (ANOVA) $(\mathrm{p}=0.95)$. The graphical analysis of the residues showed that the model was not suitable, so the authors performed a logarithmic transformation, followed by Duncan's multiple comparisons test. The test determined the significance of differences between the mean values at a 5\% significance level and divided the materials by letters from a to $\mathrm{m}$. There were no statistically significant differences between materials with the same label.

\section{RESULTS AND DISCUSSION}

Among the materials that were not exposed to weathering (control), non-treated Norway spruce had the highest roughness, regardless of the type of measurements performed. Namely, profile roughness $\left(R_{\mathrm{a}}\right)$ in a longitudinal direction, perpendicular to the grain (measurements 4 and 5) ranged from $19.4 \mu \mathrm{m}$ (PiAb), $10.8 \mu \mathrm{m}$, and $10.5 \mu \mathrm{m}$ (at TM $\mathrm{PiAb}$ and TMW PiAb) to $8.4 \mu \mathrm{m}$ with larch (LaDe) (Fig. 3L). The reason for these dependencies cannot be clearly stated, because all of the samples were prepared on the same equipment, approximately at the same time. It is known that machining of thermally modified wood can cause some difficulties (Finnish Thermowood Association 2003), but the tool used for matching appeared to be in good shape and this issue was not observed. Differences between materials were less apparent in measurements of longitudinal surfaces parallel to growth rings; all materials tested had similar roughness (Fig. 2L). For example, profile roughness with spruce was $6.6 \mu \mathrm{m}$, which was considerably lower than in the direction perpendicular to the grain $(19.4 \mu \mathrm{m}$; Fig. 3L). However, the profile roughness of spruce in this direction was comparable to the roughness of larch $(6.1 \mu \mathrm{m})$. It was slightly higher than the roughness measured with thermally modified wood (TM PaAb 5.1 $\mu \mathrm{m})$. The reason for the obtained differences presumably originates in the anatomic structure of the wood. Cracks in wood are usually positioned parallel to the grain, thus affecting the roughness measurements perpendicular to the grain (Oltean et al. 2007). In addition to profile roughness, 3D roughness was also determined. The standard deviation of the surface roughness was rather high. This is likely the result of the heterogenic nature of wood, an uneven effect of the weathering, blue-staining on the surface of the wood (Cogulet et al. 2018). 

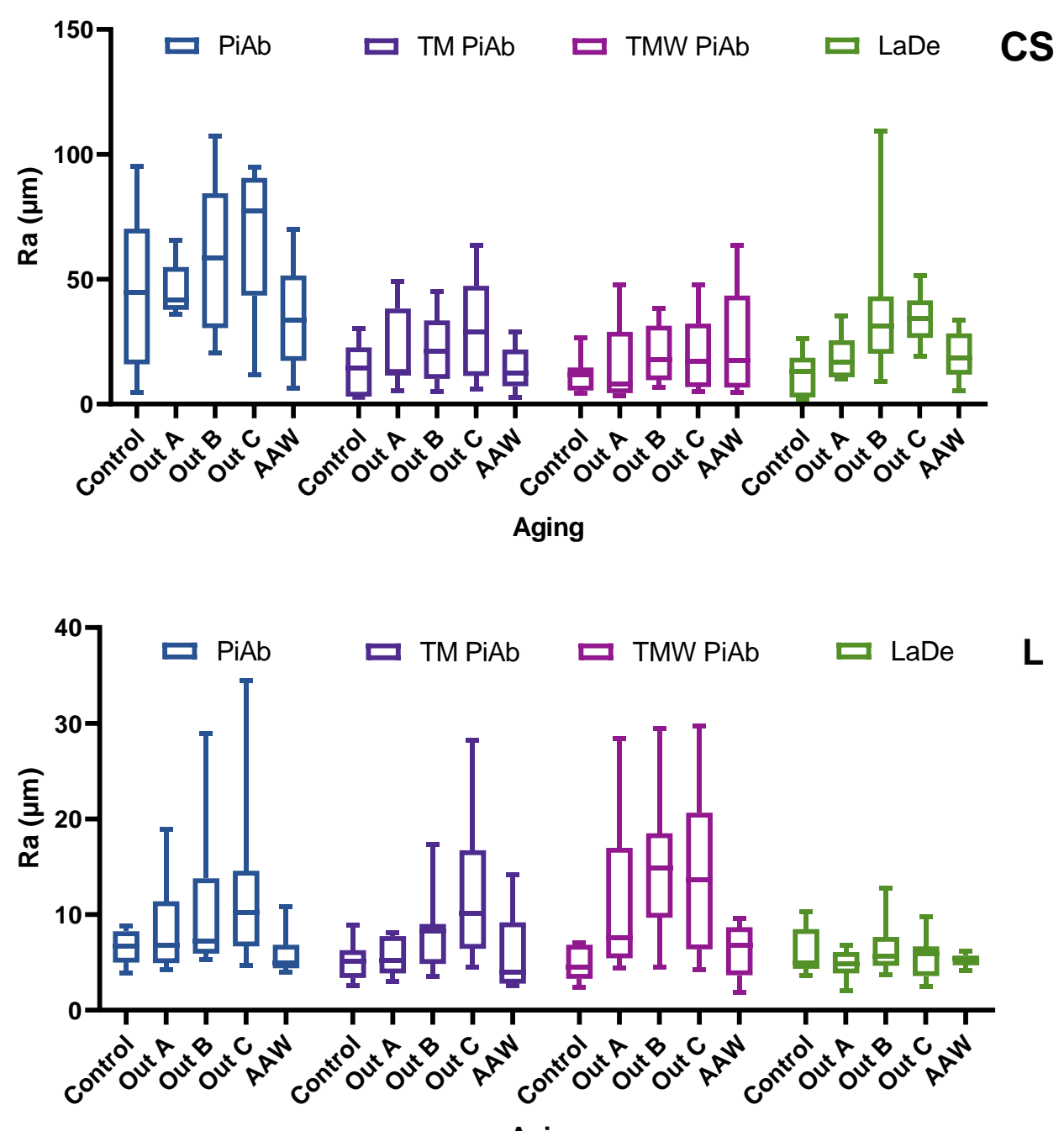

Aging

Fig. 2. Measurements of profile roughness parameter $R_{a}$ (arithmetical mean height) parallel to the growth rings (lines 1, 2, and 3 ) on cross-sectional (CS) and longitudinal (L) surfaces of Norway spruce (PiAb), thermally modified Norway spruce (TM PiAb), thermally modified wax-impregnated Norway spruce (TMW PiAb), and European larch heartwood (LaDe) specimens after exposure to various aging tests (section aging procedures), performed on images taken at $10 \times$ magnification. Statistical significance can be resolved from Table 1.

Similarly, as reported for the profile roughness at 10x magnification, the highest roughness was determined with spruce samples $(20.6 \mu \mathrm{m})$, followed by thermally modified wood (TMW PiAb $10.9 \mu \mathrm{m}$ and TM PiAb $10.4 \mu \mathrm{m}$ ) and larch (8.7 $\mu \mathrm{m})$ (Fig. 4). Those values are comparable to the measurements obtained perpendicular to the grain, indicating that cracks in line with growth have the highest influence on roughness. Roughness determined at the highest magnification (50x) was, in general, lower than at lower magnification $(10 \times)$. This result is to be expected because measurements taken at different magnifications are not always comparable. Predominantly at higher magnifications, a smaller surface is analyzed, and the resolution and depth of field is different (Olympus 2019). Similarly, as already reported, higher roughness was determined on the surface of spruce wood $\left(S_{\mathrm{a}}=9.4 \mu \mathrm{m}\right)$ than on the other materials, larch $\left(S_{\mathrm{a}}=5.3 \mu \mathrm{m}\right)$ or thermally modified wood $\left(S_{\mathrm{a}}=4.7 \mu \mathrm{m}\right)$. Roughness data were in line with literature data (Tan et al. 2012; Thoma et al. 2015). 

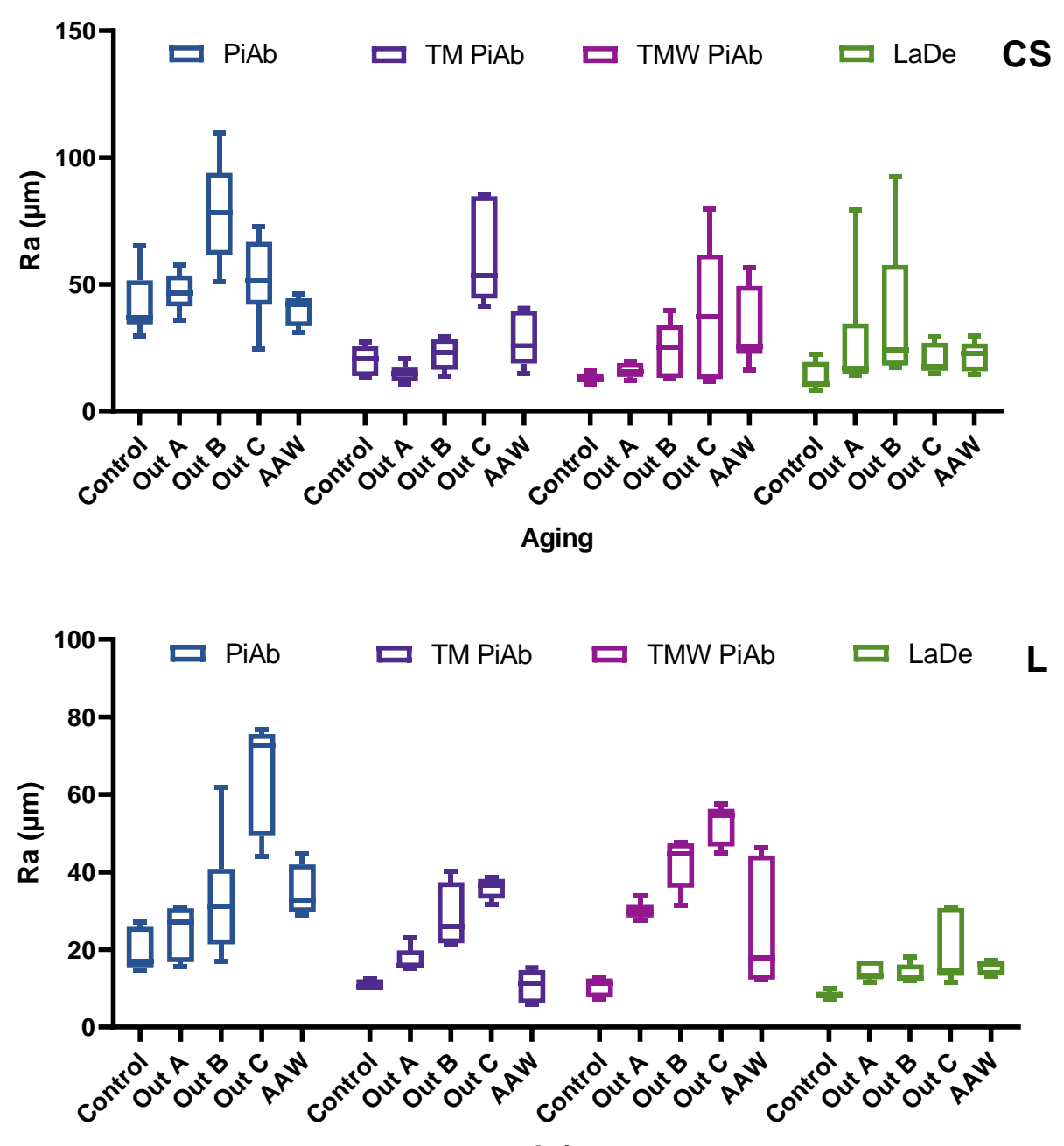

Aging

Fig. 3. Measurements of profile roughness parameter $R_{a}$ (arithmetical mean height) perpendicular to the growth rings (lines 4 and 5) on cross-sectional (CS) and longitudinal (L) surfaces of Norway spruce (PiAb), thermally modified Norway spruce (TM PiAb), thermally modified wax-impregnated Norway spruce (TMW PiAb), and European larch heartwood (LaDe) specimens after exposure to various aging tests (section aging procedures), performed on images taken at $10 \times$ magnification. Statistical significance can be resolved from Table 1.

The roughness of axial surfaces was considerably higher than the roughness of longitudinal ones (Figs. 2 through 5). This is to be expected, because machining the axial surfaces of wood is more demanding with longitudinal surfaces (Kilic et al. 2006). Among the wood species investigated, spruce wood had the highest roughness, regardless of the roughness analysis performed. The highest values on spruce wood and in general were determined with 3D analysis of the surface with $10 \times$ magnification ( $\mathrm{PiAb} 47.0 \mu \mathrm{m})$. Similar values were determined on spruce wood with profile analysis parallel ( $\mathrm{PiAb} 44.6$ $\mu \mathrm{m})$ and perpendicular to the growth ring ( $\mathrm{PiAb} 41.9 \mu \mathrm{m})$. This indicated that the cracking on axial surfaces appeared to the same extent in both directions. The share of axial surfaces in elements from real case applications was relatively small compared with the specimens used. However, wood is much more permeable in a longitudinal direction than in radial or tangential directions (Banks 1972). Axial surfaces thus often represent the weakest point of wooden elements in above-ground applications; accordingly, the assessment of axial surfaces is also important (Žlahtič and Humar 2016b). 

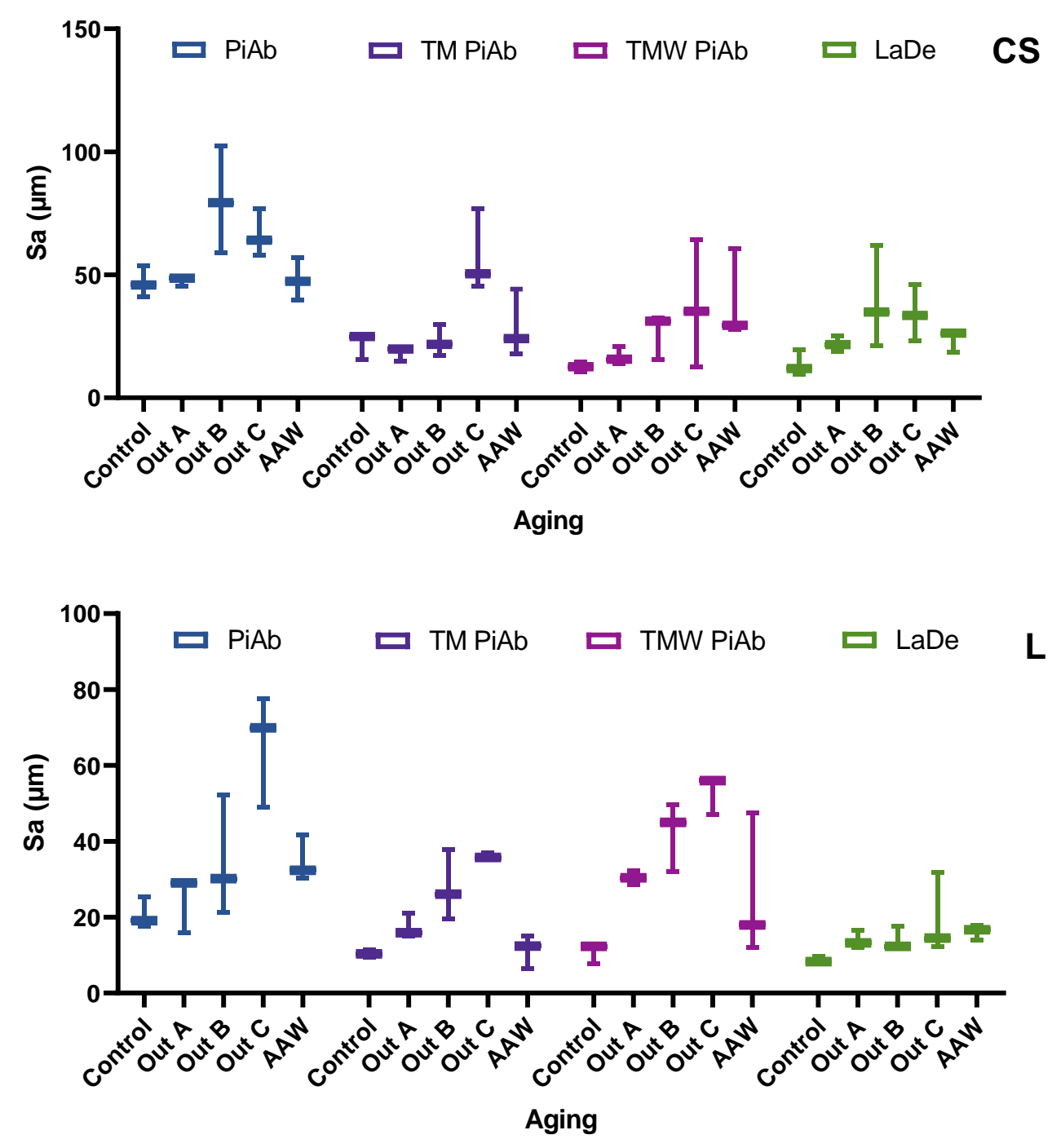

Fig. 4. Measurements of areal roughness parameter $S_{a}$ (arithmetical mean height) on crosssectional (CS) and longitudinal (L) surfaces of Norway spruce (PiAb), thermally modified Norway spruce (TM PiAb), thermally modified wax-impregnated Norway spruce (TMW PiAb), and European larch heartwood ( $\mathrm{LaDe}$ ) specimens after exposure to various aging tests (section aging procedures), performed on images taken at 10x magnification. Statistical significance can be resolved from Table 1. 

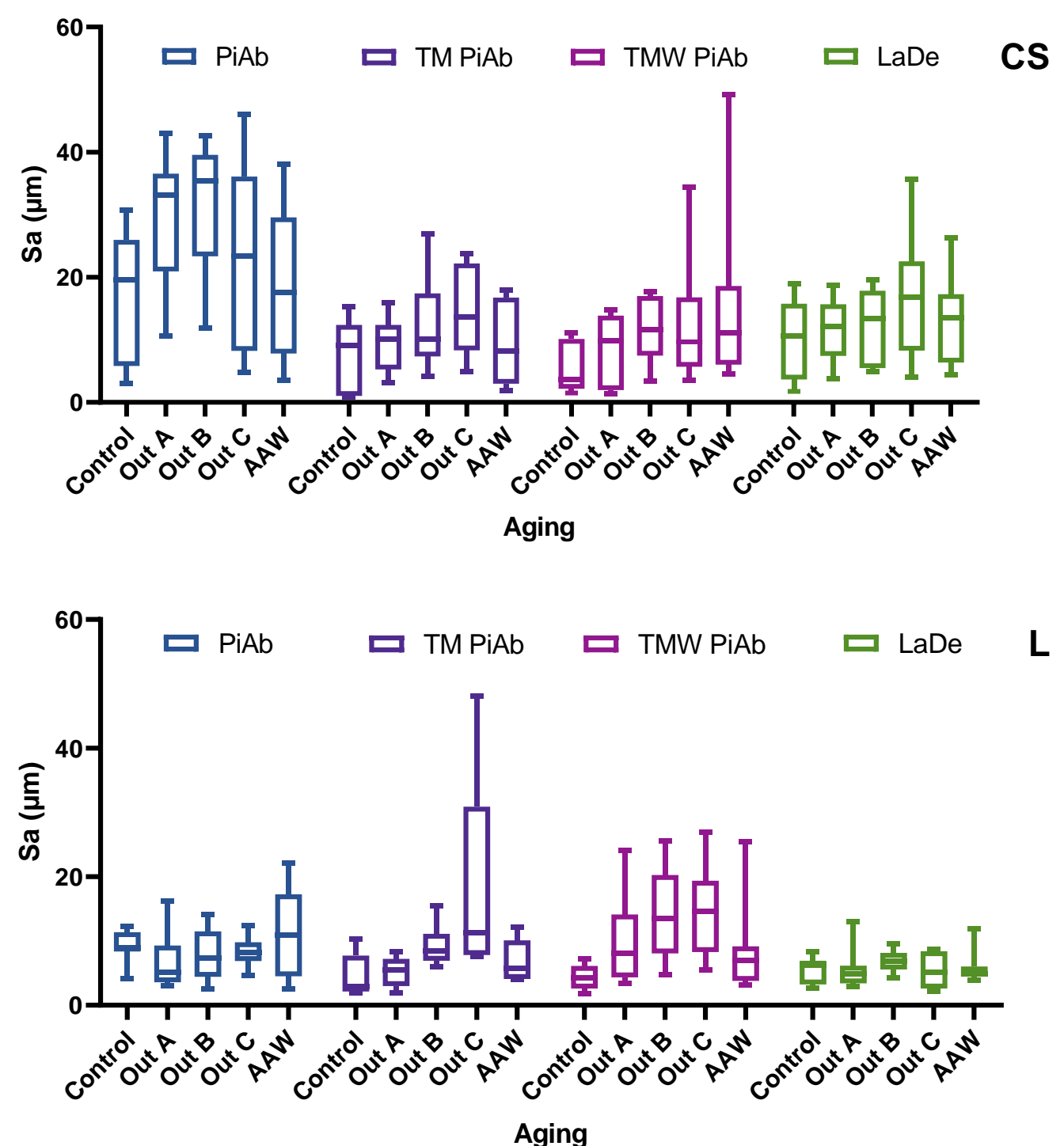

Fig. 5. Measurements of areal roughness parameter $S_{a}$ (arithmetical mean height) on crosssectional (CS) and longitudinal (L) surfaces of Norway spruce (PiAb), thermally modified Norway spruce (TM PiAb), thermally modified wax-impregnated Norway spruce (TMW PiAb), and European larch heartwood ( $\mathrm{LaDe}$ ) specimens after exposure to various aging tests (section aging procedures), performed on images taken at $50 \times$ magnification. Statistical significance can be resolved from Table 1.

Artificial accelerated weathering is frequently used to imitate abiotic weathering phenomena. In general, AAW conditions are too harsh to enable the infestation of wood with fungi (decay and stains) (Žlahtič and Humar 2016b; Kržišnik et al. 2018b). Therefore, changes predominantly reflect the effect of UV and IR (infrared) radiation and artificial rain events. On axial planes, a fairly uniform effect was determined. The roughness of the spruce wood after AAW remained in the same range, regardless of the magnification by which roughness was established. In contrast, roughness changes of larch wood were more noticeable. On average (except for the 3D roughness determined at the highest magnification), roughness increased approximately 60\% (Figs. 2 through 5). The 
roughness of thermally modified wood increased approximately $30 \%$ after AAW. The highest increase in roughness was observed with wax-treated wood. This increase was evident at both magnifications, and was even higher after artificial weathering than after 27 month of natural weathering. This may be an effect of melting or crystallization of the wax, which appears due to high temperatures and the leaching of surfactants during AAW (Lesar et al. 2011). It should be considered that the axial planes were exposed to intensive radiation during AAW, while the axial planes of the specimens exposed outdoors were less exposed to the sun radiation due to the construction of the rack.

Although the roughness of the spruce remained stable during AAW, the roughness of this wood species remained the highest among the tested materials. Comparing these data to the literature data on moisture performance, it can be seen that short-term water uptake into thermally modified wood from axial surfaces increased more prominently than with the other tested materials. Therefore, the increase of roughness cannot be the only mechanism that contributes to increased water uptake from axial surfaces. A similar effect was also determined on longitudinal surfaces. Changes in roughness parallel to the grain were less prominent than the $R_{\mathrm{a}}$ values determined perpendicular to the grain and 3D ones $\left(S_{\text {a }}\right)$. At $10 \times$ magnification, the lowest increase in roughness was determined on thermally modified wood. This might be associated with the dimensional stability of thermally modified wood (Tjeerdsma et al. 1998; Hill 2006; Esteves and Pereira 2009). The highest increase in roughness was determined on wax-treated thermally modified wood (TMW $\mathrm{PiAb}$ ). The roughness of wax-treated wood increased 1.88 to 2.37 times (Figs. 2 through 5). The roughness increase of AAW larch on longitudinal surfaces was similar to the roughness increase on axial surfaces.

The effect of outdoor weathering on wood roughness was more complex than the effect of AAW. When exposed to weathering, the trend of increasing roughness with exposure time was similar for all treatments (Figs. 2 through 5). The average, roughness increased 55\% after the first 9 months of weathering (OutA), by $100 \%$ after 18 months of weathering (OutB), and by $150 \%$ after 27 months of weathering (OutC). The average increase after 9 months of weathering was higher than after AAW. It should be noted that the naturally weathered samples were exposed to the whole range of biotic and abiotic factors. As observed from the surface of weathered samples (Fig. 6), there are melamine deposits, which also influence the chemical composition of the wood. In addition, fungal hyphae penetrate through the pits to the inner cells, which also affects the permeability (Thaler et al. 2012).

As a result of the weathering, roughness increased more prominently perpendicular to the growth rings than parallel to them (Figs. 2 and 3). This may be a result of the anatomical features, as already described. Cracks are more likely to form between the cells than perpendicular to them. The roughness increase expressed as $S_{\mathrm{a}}$, determined at $10 \times$ magnification, was more prominent on longitudinal than on axial surfaces. For example, the roughness of wax-treated thermally modified spruce (TMW PaAb) increased from an initial $10.9 \mu \mathrm{m}$ (Control; $S_{\text {a }}$ ) to $30.3 \mu \mathrm{m}\left(\right.$ OutA; $S_{\text {a }}$ ) after 9 months, through $42.2 \mu \mathrm{m}$ (OutB; $\mathrm{Sa}$ ) after 18 months to $53.1 \mu \mathrm{m}$ (OutC; Sa) after 27 months of weathering (Fig. 4). A similar trend was observed with spruce wood (PiAb) and thermally modified wood (TM PaAb). The only exception was larch heartwood samples, with which a roughness increase was observable but less prominent than with spruce-derived materials. 


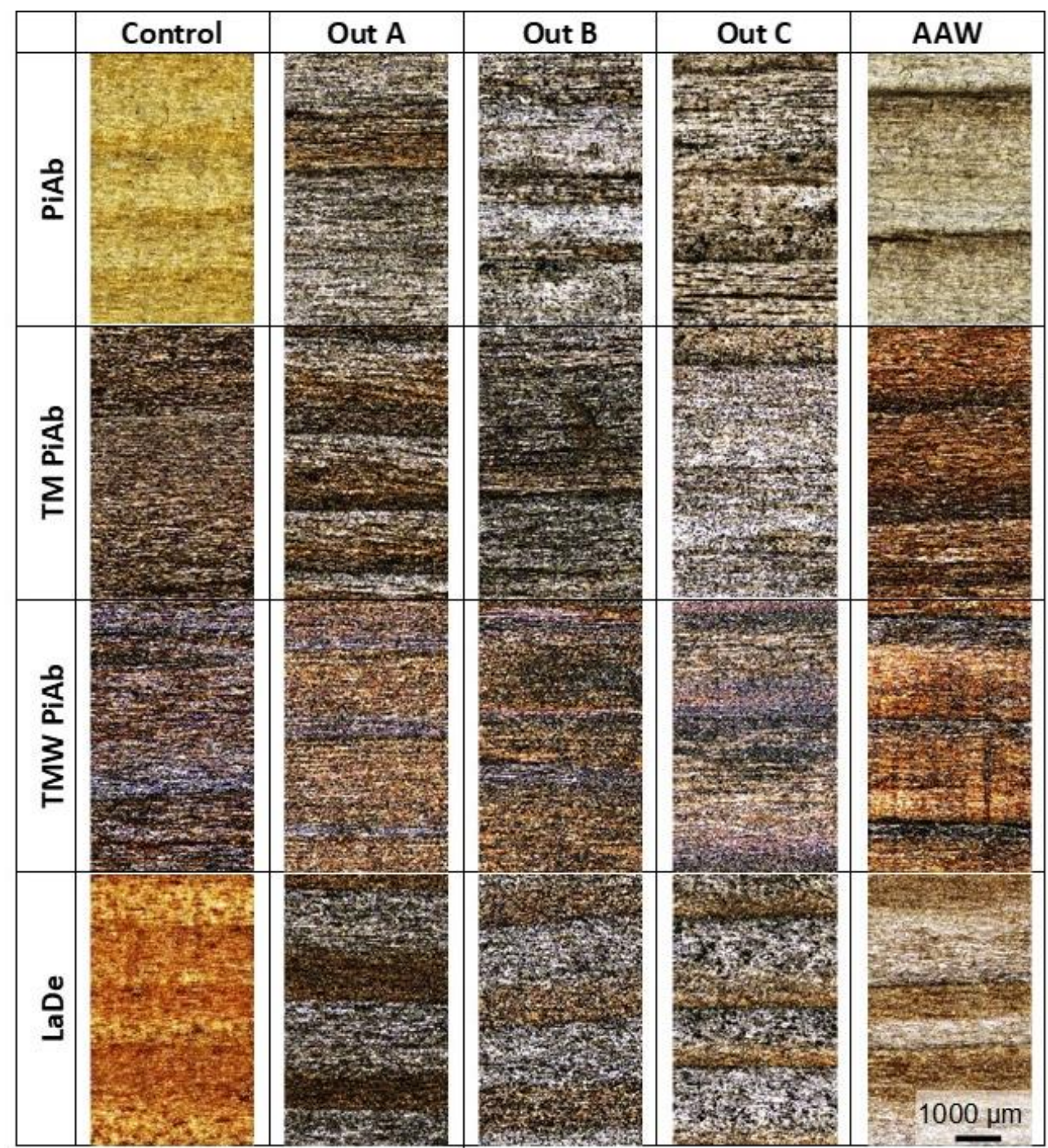

Fig. 6. Microscopic pictures of longitudinal $(L)$ surfaces of Norway spruce (PiAb), thermally modified Norway spruce (TM PiAb), thermally modified wax-impregnated Norway spruce (TMW $\mathrm{PiAb})$, and European larch heartwood ( $\mathrm{LaDe}$ ) specimens after exposure to various aging tests (section aging procedures), performed on images taken at $10 \times$ magnification. The area size was $3.6 \mathrm{~mm} \times 5.9 \mathrm{~mm}$.

It is difficult to determine the reasons for these differences. They might be associated with the better durability of larch wood and better water performance compared to spruce wood (Brischke et al. 2013; Meyer-Veltrup et al. 2017). If roughness at higher magnification $(50 \times)$ is considered, it can be concluded that the roughness of cross-sections remained in the same range, except for wax-treated thermally modified wood (TMW $\mathrm{PiAb}$ ). However, on longitudinal surfaces, the roughness of spruce wood (PiAb; $S_{\mathrm{a}}$ ) stayed

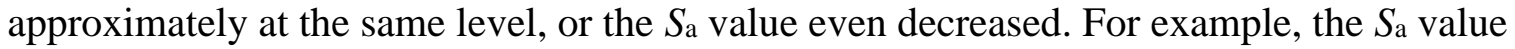
of unexposed (control) spruce wood was $9.4 \mu \mathrm{m}$, and this value decreased to $8.3 \mu \mathrm{m}$ after 27 months of weathering (Fig. 5). A similar phenomenon was noted with larch heartwood

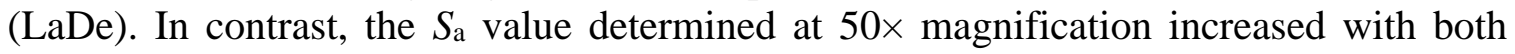
thermally modified wood (TM PiAb) and wax-treated thermally modified wood (TMW $\mathrm{PiAb}$ ). The roughness of thermally modified wood (TM PiAb, $S_{\mathrm{a}}, 50 \times$ ) increased from 4.7 (control) to $5.1 \mu \mathrm{m}$ after 9 months (OutA, $S_{\text {a }}$, through $9.2 \mu \mathrm{m}\left(\mathrm{OutB} ; S_{\mathrm{a}}\right.$ ) after 18 months 
to $18.5 \mu \mathrm{m}$ (OutC; Sa) after 27 months of weathering (Fig. 5). Similarly, the roughness increased with wax-treated thermally modified wood.

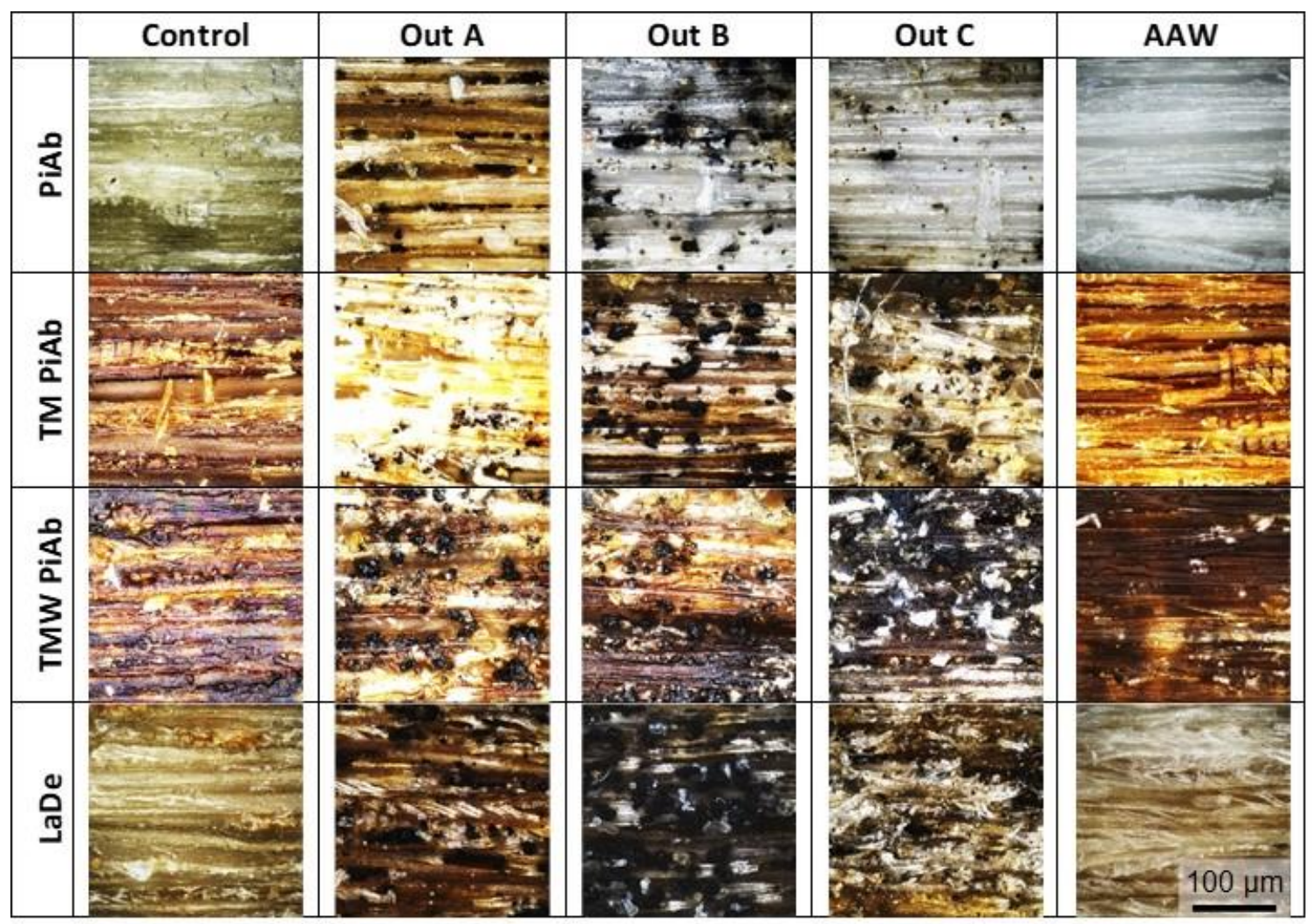

Fig. 7. Microscopic pictures of longitudinal (L) surfaces of Norway spruce (PiAb), thermally modified Norway spruce (TM PiAb), thermally modified wax-impregnated Norway spruce (TMW $\mathrm{PiAb})$, and European larch heartwood ( $\mathrm{LaDe}$ ) specimens after exposure to various aging tests (section aging procedures), performed on images taken at $50 \times$ magnification. The area size was $256 \mu \mathrm{m} \times 256 \mu \mathrm{m}$.

If roughness data are linked to water performance (Laskowska et al. 2016; ŽlahtičZupanc et al. 2018), it can be seen that the four materials can be divided into three categories; (1) the water performance of spruce and larch after weathering slightly decreased; (2) the decrease of water performance with thermally modified wood was greatest, regardless of the methods used (short term water uptake, 1-h immersion, contact angle, etc.). In contrast, (3) with wax-treated thermally modified wood, the moisture performance even slightly improved (Žlahtič-Zupanc et al. 2018). This is in line with Wenzel's theory (Wenzel 1936; Petrič and Oven 2015). Namely, increased roughness will decrease the contact angle on hydrophilic surfaces. The roughness of spruce and larch does not change significantly (when measured at the highest magnification). This accords with the small changes of water performance (contact angle, water uptake after immersion, etc.) after weathering. However, roughness increased significantly with thermally modified wood. Because the contact angles of water on thermally modified wood are close to $90^{\circ}$ (Žlahtič-Zupanc et al. 2018), increased roughness resulted in decreased contact angles and, consequently, increased water uptake. The contact angles on thermally modified spruce wood decreased from $90^{\circ}$ to $53^{\circ}$ after 27 months of weathering (OutC) (Žlahtič-Zupanc et al. 2018). In contrast, the contact angles of wax-treated wood are higher. They are 
positioned between $100^{\circ}$ and $110^{\circ}$ (Humar et al. 2017). According to Wenzel's theory, increased roughness will increase the measured contact angle on hydrophobic surfaces. Increased roughness therefore results in higher contact angles and improved water performance. After weathering, the contact angles on wax-treated thermally modified wood increased from $105^{\circ}$ to $124^{\circ}$ after 27 months of weathering (OutC) (Žlahtič-Zupanc et al. 2018). The authors are aware that roughness is not the only mechanism affecting water performance. In addition to roughness, the decreased water performance of weathered wood can be ascribed to fungal infestation, potential degradation of deposits on the pit's membranes, changes in the chemical structure of the surface, etc. (Žlahtič-Zupanc et al. 2018). However, the present results indicate one of the possible mechanisms affecting the water performance of thermally modified wood.

Table 1. Results of the Statistical Analysis of the Roughness

\begin{tabular}{|c|c|c|c|c|c|c|c|c|c|}
\hline \multirow{2}{*}{ Material } & \multirow{2}{*}{ Aging } & \multicolumn{4}{|c|}{ Profile Roughness } & \multicolumn{4}{|c|}{ Areal Roughness } \\
\hline & & $123 \mathrm{CS}$ & 123L & 45CS & $45 \mathrm{~L}$ & $10 \times C S$ & $10 \times L$ & $50 \times C S$ & $50 \times L$ \\
\hline \multirow{5}{*}{$\frac{0}{2}$} & Control & $a b c$ & cdef & bcd & ghij & abcd & defg & bcde & $a b c$ \\
\hline & Out $A$ & $a b$ & bcdef & $\mathrm{bc}$ & efgh & abcd & cdefg & $a b$ & cdefg \\
\hline & Out B & a & abcde & a & def & a & bcd & a & cdef \\
\hline & Out C & a & $a b c$ & $a b c$ & $\mathrm{a}$ & $a b$ & $a$ & $a b c$ & abcde \\
\hline & AAW & $a b c$ & ef & bcd & cde & abcd & bcd & abcd & abcd \\
\hline \multirow{5}{*}{ 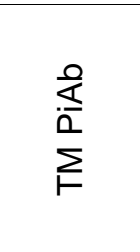 } & Control & e & $f$ & efghi & $\mathrm{klm}$ & efgh & hi & $\mathrm{fg}$ & g \\
\hline & Out A & cde & $f$ & ghi & hij & fgh & fgh & cdefg & efg \\
\hline & Out B & cde & bcdef & efg & efg & efgh & cdef & cde & abcd \\
\hline & Out C & $\mathrm{bcd}$ & $a b c$ & $a b$ & bcde & $a b c$ & bcd & bcde & $\mathrm{a}$ \\
\hline & AAW & de & $f$ & def & $\mathrm{Im}$ & defg & hi & defg & colefg \\
\hline \multirow{5}{*}{ 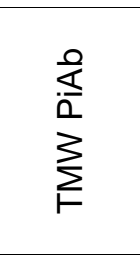 } & Control & e & $f$ & hi & Im & $\mathrm{h}$ & hi & g & $\mathrm{fg}$ \\
\hline & Out $A$ & de & abcd & fghi & $a b c$ & gh & cde & efg & bcde \\
\hline & Out B & cole & a & efg & bcd & defg & $a b c$ & cde & $a b$ \\
\hline & Out C & cde & $a b$ & cde & $a b$ & cdefg & $a b$ & cdef & $a b$ \\
\hline & AAW & cde & def & cde & fghi & bcde & defg & cde & cdefg \\
\hline \multirow{5}{*}{$\stackrel{\Xi}{\text { Фิ }}$} & Control & e & def & i & $\mathrm{m}$ & $\mathrm{h}$ & $\mathrm{i}$ & defg & defg \\
\hline & Out $A$ & cde & $f$ & efgh & jkl & efgh & ghi & cde & defg \\
\hline & Out B & $a b c$ & def & cde & jkl & bcde & ghi & cde & colefg \\
\hline & Out C & $a b c$ & $f$ & efghi & hij & cdef & efgh & bcde & efg \\
\hline & AAW & cde & $f$ & efgh & ijk & efgh & fgh & cde & cdefg \\
\hline
\end{tabular}

Different letters indicate a statistically significant difference $(p>0.05)$ between different materials and aging periods tested. Abbreviation indicates location (CS (cross-sectional) and $L$ (longitudinal) surfaces), direction (123 (profile roughness parallel to the growth rings); 45 (profile roughness perpendicular to the growth rings)), and magnification (10x and 50x). 


\section{CONCLUSIONS}

1. After the weathering of spruce, thermally modified spruce, wax-treated thermally modified wood, and larch heartwood, the roughness increased on axial and longitudinal surfaces. This can be seen from both the profile 2D measurements $\left(R_{\mathrm{a}}\right)$ and the surface 3D measurements $\left(S_{\mathrm{a}}\right)$.

2. There is no major difference between $2 \mathrm{D}$ and 3D measurements. However, 3D measurements are more representative, as they cover wider area and are less subjective than 2D measurements. Selection of the magnification defines the scale of the measurements. Measurements at higher magnifications (50x) enables observation on cellular level, while lower magnification (10x) showed the changes on macro scale.

3. The roughness of the weathered materials increased with increasing duration of weathering. The effect of natural weathering on roughness was higher than artificial accelerated weathering, presumably due to the synergistic effects of abiotic and biotic factors.

4. Roughness, determined at the highest magnification, can partially explain the decrease of water performance of thermally modified wood after weathering. This accords with Wenzel's theory that increased roughness will decrease the contact angle on hydrophilic surfaces.

5. In contrast, increased roughness had a positive effect on wax-treated thermally modified wood, because increased roughness increased the measured contact angle on hydrophobic surfaces. This may be one of the explanations for the moisture performance of wood in outdoor applications.

\section{ACKNOWLEDGMENTS}

The authors acknowledge the support of the Slovenian Research Agency (ARRS) within the framework of research project L4-7547, research program P4-0015, and the infrastructural center (IC LES PST 0481-09). Part of the presented research was also supported by the project "Wood and wood products over a lifetime" (WOOLFOP20.03520).

\section{REFERENCES CITED}

Banks, W. B. (1972). "Factors affecting the introduction of preservatives into wood," Pestic. Sci. 3(2), 219-227. DOI: 10.1002/ps.2780030217

Brischke, C., Meyer, L., Alfredsen, G., Humar, M., Francis, L., Flæte, P.-O., and Larsson-Brelid, P. (2013). "Natural durability of timber exposed above ground - A survey," Drvna Ind. 64(2), 113-129. DOI: 10.5552/drind.2013.1221

Brito, A. F., Calonego, F. W., Bond, B. H., and Severo, E. T. D. (2018). "Color changes, EMC, and biological resistance of thermally modified yellow poplar," Wood. Fiber Sci. 50(4), 439-446. DOI: 10.22382/wfs-2018-055

Cerc Korošec, R., Lavrič, B., Rep, G., Pohleven, F., and Bukovec, P. (2009).

"Thermogravimetry as a possible tool for determining modification degree of 
thermally treated Norway spruce wood," J. Therm. Anal. Calorim. 98(1), 189-195. DOI: $10.1007 / \mathrm{s} 10973-009-0374-\mathrm{Z}$

Cheung, K. C. K. (2019). "Wooden structures," Reference Module in Materials Science and Materials Engineering 1(1), 1-14. DOI: 10.1016/B978-0-12-803581-8.02225-6

Cogulet, A., Blanchet, P., and Landry, V. (2018). "The multifactorial aspect of wood weathering: A review based on a holistic approach of wood degradation protected by clear coating," BioResources 13(1), 2116-2138. DOI: 10.15376/biores.13.1.Cogulet

EN 113 (2006). "Wood preservatives: Test method for determining the protective effectiveness against wood destroying basidiomycetes : Determination of the toxic values," European Committee for Standardization, Brussels, Belgium.

EN 335 (2013). "Durability of wood and wood-based products - Use classes: Definitions, application to solid wood and wood-based products," European Committee for Standardization, Brussels, Belgium.

EN 350 (2016). "Durability of wood and wood-based products. Testing and classification of the durability to biological agents of wood and wood-based materials," European Committee for Standardization, Brussels, Belgium.

EN 11341 (2004). "Paints and varnishes - Artificial weathering and exposure to artificial radiation - Exposure to filtered xenon-arc radiation," European Committee for Standardization, Brussels, Belgium.

Esteves, B. M., and Pereira, H. M. (2009). "Wood modification by heat treatment: A review," BioResources 4(1), 370-404.

European Union (EU) Commission (2019). "Woodworking, internal market, industry, entrepreneurship and SMEs," (https://ec.europa.eu/growth/sectors/rawmaterials/industries/forest-based/woodworking_en), Accessed 29 March 2020.

Finnish Thermowood Association (2003). ThermoWood Handbook, Finnish Thermowood Association, Helsinki, Finland.

Gadelmawla, E. S., Koura, M. M., Maksoud, T. M. A., Elewa, I. M., and Soliman, H. H. (2002). "Roughness parameters," J. Mater. Process. Tech. 123(1), 133-145. DOI: 10.1016/S0924-0136(02)00060-2

Goli, G., and Todaro, L. (2018). "Wood modification in Europe: Processes, products, applications," in: Proceedings of the COST Action FP1407 WG1 and WG4 Meeting (Vol. 26), University of Florence, Florence, Italy, pp. 41.

Hill, C. A. S. (2006). Wood Modification: Chemical, Thermal and Other Processes, John Wiley \& Sons, Hoboken, NJ, USA. DOI: 10.1002/0470021748

Hill, C. A. S., Ramsay, J., Keating, B., Laine, K., Rautkari, L., Hughes, M., and Constant, B. (2012). "The water vapour sorption properties of thermally modified and densified wood," J. Mater. Sci. 47(7), 3191-3197. DOI: 10.1007/s10853-011-6154-8

Humar, M. (2017). "Protection of the bio-based material," in: Performance of Bio-based Building Materials, J. Dennis and C. Brischke (eds.), Woodhead Publishing, Duxford, England, pp. 187-240. DOI: 10.1016/B978-0-08-100982-6.00004-5

Humar, M., Kržišnik, D., Lesar, B., Thaler, N., Ugovšek, A., Zupančič, K., and Žlahtič, M. (2017). "Thermal modification of wax-impregnated wood to enhance its physical, mechanical, and biological properties," Holzforschung 71(1), 57-64. DOI: 10.1515/hf-2016-0063

Humar, M., Kržišnik, D., Lesar, B., and Brischke, C. (2019). "The performance of wood decking after five years of exposure: Verification of the combined effect of wetting ability and durability," Forests 10(10), Article number 903. DOI: 10.3390/f10100903

Humar, M., Lesar, B., and Kržišnik, D. (2020a). "Technical and aesthetic service life of 
wood," Acta Silvae et Ligni 121, 33-48. DOI: 10.20315/asetl.121.3

Humar, M., Lesar, B., and Kržišnik, D. (2020b). "Moisture performance of façade elements made of thermally modified Norway spruce wood," Forests 11(3), Article number 348. DOI: 10.3390/f11030348

Kilic, M., Hiziroglu, S., and Burdurlu, E. (2006). "Effect of machining on surface roughness of wood," Build. Environ. 41(8), 1074-1078. DOI:

10.1016/j.buildenv.2005.05.008

Kozakiewicz, P., Drozdzek, M., Laskowska, A., Grześkiewicz, M., Bytner, O., Radomski, A., and Zawadzki, J. (2019). "Effects of thermal modification on selected physical properties of sapwood and heartwood of black poplar (Populus nigra L.)," BioResources 14(4), 8391-8404. DOI: 10.15376/biores.14.4.8391-8404

Kržišnik, D., Lesar, B., Thaler, N., and Humar, M. (2018a). "Micro and material climate monitoring in wooden buildings in sub-Alpine environments," Constr. Build. Mater. 166, 188-195. DOI: 10.1016/j.conbuildmat.2018.01.118

Kržišnik, D., Lesar, B., Thaler, N., and Humar, M. (2018b). "Influence of natural and artificial weathering on the colour change of different wood and wood-based materials," Forests 9(8), Article number 488. DOI: 10.3390/f9080488

Kutnik, M., Suttie, E., and Brischke, C. (2014). "European standards on durability and performance of wood and wood-based products - Trends and challenges," Wood Mater. Sci. Eng. 9(3), 122-133. DOI: 10.1080/17480272.2014.894574

Laskowska, A., Dobrowolska, E., and Boruszewski, P. (2016). "The impact of ultraviolet radiation on the colour and wettability of wood used for facades," Drewno 59(197), 99-111. DOI: 10.12841/wood.1644-3985.C12.16

Lesar, B., Kržišnik, D., and Humar, M. (2019). "Decay and water resistance of Siberian and European larch wood," in: Proceedings of the 50 ${ }^{\text {th }}$ Annual Meeting of the International Research Group on Wood Protection, Quebec, Canada, Doc. no. IRG/WP 19-10941.

Lesar, B., Pavlič, M., Petrič, M., Škapin, A. S. A. S., and Humar, M. (2011). "Wax treatment of wood slows photodegradation," Polym. Degrad. Stabil. 96(7), 12711278. DOI: $10.1016 /$ j.polymdegradstab.2011.04.006

Martínez, Á. T., Speranza, M., Ruiz-Dueñas, F. J., Ferreira, P., Camarero, S., Guillén, F., Martínez, M. J., Gutiérrez, A., and Del Río, J. C. (2005). "Biodegradation of lignocellulosics: Microbial, chemical, and enzymatic aspects of the fungal attack of lignin," Int. Microbiol. 8(3), 195-204. DOI: 10.13039/501100003339

Metsä-Kortelainen, S. (2011). "Differences between sapwood and heartwood of thermally modified Norway spruce (Picea abies) and Scots pine (Pinus sylvestris) under water and decay exposure," VTT Publications (771), 1-58.

Meyer-Veltrup, L., Brischke, C., Alfredsen, G., Humar, M., Flæte, P. O., Isaksson, T., Brelid, P. L., Westin, M., and Jermer, J. (2017). "The combined effect of wetting ability and durability on outdoor performance of wood: Development and verification of a new prediction approach," Wood Sci. Technol. 51(3), 615-637. DOI: 10.1007/s00226-017-0893-x

Militz, H. (2015). "Wood modification in Europe in the year 2015: A success story?," in: The Eighth European Conference on Wood Modification, H. Mark, L. Rautkari, U. Tuuli, J. Brigitte, and H. Militz (eds.), Aalto University, Helsinki, Finland, pp. 1-4.

Nasir, V., Nourian, S., Avramidis, S., and Cool, J. (2019). "Classification of thermally treated wood using machine learning techniques," Wood Sci. Technol. 53(1), 275288. DOI: $10.1007 / \mathrm{s} 00226-018-1073-3$ 
Olek, W., Majka, J., and Czajkowski, Ł. (2013). "Sorption isotherms of thermally modified wood," Holzforschung 67(2), 183-191. DOI: 10.1515/hf-2011-0260

Oltean, L., Teischinger, A., and Hansmann, C. (2007). "Influence of temperature on cracking and mechanical properties of wood during wood drying - A review," BioResources 2(4), 789-811. DOI: 10.15376/biores.2.4.789-811

Olympus (2019). LEXT OLS5000, Olympus Corporation, Tokyo, Japan.

Pelaez-Samaniego, M. R., Yadama, V., Lowell, E., and Espinoza-Herrera, R. (2013). “A review of wood thermal pretreatments to improve wood composite properties,"Wood Sci. Technol. 47(6), 1285-1319. DOI: 10.1007/s00226-013-0574-3

Petrič, M., and Oven, P. (2015). "Determination of wettability of wood and its significance in wood science and technology: A critical review," Reviews of Adhesion and Adhesives 3(2), 121-187. DOI: 10.7569/RAA.2015.097304

Rep, G., Pohleven, F., and Kosmerl, S. (2012). "Development of the industrial kiln for thermal wood modification by a procedure with an initial vacuum and commercialisation of modified Silvapro wood," in: Proceedings of the 6th European Conference on Wood Modification, D. Jones, H. Militz, M. Petrič, F. Pohleven, M. Humar, and M. Pavlič (eds.), University of Ljubljana, Ljubljana, Slovenia, pp. 11-17.

Scheiding, W., Direske, M., and Zauer, M. (2016). "Water absorption of untreated and thermally modified sapwood and heartwood of Pinus sylvestris L.," Eur. J. Wood Wood Prod. 74(4), 585-589. DOI: 10.1007/s00107-016-1044-z

Tan, P. L., Sharif, S., and Izman, S. (2012). "Roughness models for sanded wood surfaces," Wood Sci. Technol. 46(1), 129-142. DOI: 10.1007/s00226-010-0382-y

Thaler, N., Lesar, B., Kariž, M., and Humar, M. (2012). "Bioincising of Norway spruce wood using wood inhabiting fungi," Int. Biodeter. Biodegr. 68, 51-55. DOI: 10.1016/j.ibiod.2011.11.014

Thoma, H., Peri, L., and Lato, E. (2015). "Evaluation of wood surface roughness depending on species characteristics," Maderas-Cienc. Tecnol. 17(2), 285-292. DOI: 10.4067/S0718-221X2015005000027

Tjeerdsma, B. F., Boonstra, M., Pizzi, A., Tekely, P., and Militz, H. (1998). "Characterisation of thermally modified wood: Molecular reasons for wood performance improvement," Holz. Roh. Werkst. 56(3), 149-153. DOI: $10.1007 / \mathrm{s} 001070050287$

Tjeerdsma, B. F., and Militz, H. (2005). "Chemical changes in hydrothermal treated wood: FTIR analysis of combined hydrothermal and dry heat-treated wood," Holz. Roh. Werkst. 63(2), 102-111. DOI: 10.1007/s00107-004-0532-8

Van Acker, J., Van den Bulcke, J., De Windt, I., Colpaert, S., and Li, W. (2015). "Moisture dynamics of modified wood and the relevance towards decay resistance," in: 8th European Conference on Wood Modification (ECWM8), Helsinki, Finland, pp. 44-55.

Welzbacher, C. R., Brischke, C., Rapp, A. O., Koch, S., and Hofer, S. (2009). "Performance of thermally modified timber (TMT) in outdoor application durability, abrasion and optical appearance," Drvna Ind. 60(2), 75-82. DOI: $10.15488 / 2011$

Wenzel, R. N. (1936). "Resistance of solid surfaces to wetting by water," Ind. Eng. Chem. 28(8), 988-994. DOI: 10.1021/ie50320a024

Yildiz, S., Yildiz, U. C., and Tomak, E. D. (2011). "The effects of natural weathering on the properties of heat-treated alder wood," BioResources 6(3), 2504-2521. DOI: 10.15376/biores.6.3.2504-2521 
Zauer, M., Kowalewski, A., Sproßmann, R., Stonjek, H., and Wagenführ, A. (2016). "Thermal modification of European beech at relatively mild temperatures for the use in electric bass guitars," Eur. J. Wood. Wood Prod.74(1), 43-48. DOI: 10.1007/s00107-015-0973-2

Žlahtič, M., and Humar, M. (2016a). "Influence of artificial and natural weathering on the moisture dynamic of wood," BioResources 12(1), 117-142. DOI: 10.15376/biores.12.1.117-142

Žlahtič, M., and Humar, M. (2016b). "Influence of artificial and natural weathering on the hydrophobicity and surface properties of wood," BioResources 11(2), 4964-4989. DOI: 10.15376/biores.11.2.4964-4989

Žlahtič-Zupanc, M., Lesar, B., and Humar, M. (2018). "Changes in moisture performance of wood after weathering," Constr. Build. Mater. 193, 529-538. DOI: 10.1016/j.conbuildmat.2018.10.196

Article submitted: November 22, 2020; Peer review completed: March 6, 2021; Revised version received and accepted: March 9, 2021; Published: May 4, 2021.

DOI: $10.15376 /$ biores.16.3.4675-4692 